NOW available from the Consejo Superior de Investigaciones Científicas in Madrid is Volumen III: Tomo Primero y Tomo Segundo, of Richard Konetzke's Colección de documentos para la historia de la formación social de Hispanoamérica, 1493-1810. The first book of the duo covers the period, 1691-1779. The second, 1780-1807.

\title{
RECENT DEATHS
}

Reverend David Rubio, O. S. A., died on December 28, 1962, in Madrid, after a seven month hospitalization in the Clínica de la Concepción.

Born in the city of León in Spain in 1884, he entered the Augustinian Order in the Province of Valladolid and in 1907 was ordained a priest in La Vid, Burgos. He received doctorates in Romance Languages and Literature from the University of San Marcos of Lima, Peru, in 1912, and the University of Madrid in 1926. During the period from 1908 to 1914 he taught in Augustinian colleges in Peru and in 1915 in Santiago, Chile. In 1918 and 1919 he taught in like institutions in Havana, Cuba. He came to the United States in 1920 and became a naturalized citizen in 1928. In 1920 and 1921 he taught at the University of Villanova in Philadelphia and from 1922 to 1926 at the University of Pennsylvania. From 1926 until his retirement in 1949 he was a professor at the Catholic University of America in Washington, D.C., and served for a time as Chairman of the Department of Romance Languages and Literature there. During this time, from 1931 to 1943, he assisted the Library of Congress in Washington as a consultant in Spanish Literature. In 1939 he was made curator of their Hispanic Collection and was connected with the founding of their Hispanic Foundation in the same year. He was an active member of any number of educational and bibliographic societies and a corresponding member of the Spanish Academy and the Hispanic Society of America.

His published works reflect his role as literary scholar, professor, and librarian. Such are: Peralvillo de Omaña (Madrid, 1921); Hay una filosófía en el Quijote? (New York, 1924); La Universidad de San Marcos de Lima durante la colonización española (Madrid, 1933); Symbolism and Classicism in Modern Literature: an Introduction to the Study of Symbolism in Spanish and Spanish American Literature (Philadelphia, 1923); Classical Scholarship in Spain (Washington, D. C., 1934); A Glossary of Technical Library and Allied Terms in Spanish and English (Washington, D. C., 1936); and The Mystic Soul of Spain (New York, 1946). 